\title{
Problems of Philosophy
}

General Editor: D. J. O'CONNOR

Each volume in this series provides a short introductory study of one of the main problems of philosophy. An account is given of the ways in which the given problem has been seen in the history of philosophy, and of the principal solutions which philosophers have advanced.

An important feature of the series is that in each study the language and the treatment are as simple as is compatible with a serious presentation of the philosophical difficulties. A full bibliography is included.

\section{Published}

Truth Alan R. White

Body And Mind Keith Campbell

Memory Don Locke

In Preparation

$$
\begin{aligned}
& \text { Perception G. N. A. Vesey } \\
& \text { Human Action G. Langford } \\
& \text { Free Will D. J. O'Connor }
\end{aligned}
$$

Substance and Property A. P. Cavendish

UNIVERSALS H. Staniland

Explanation C. B. Wright

The A Priori R. W. Ashby

Knowledge AND Belief R. J. Ackermann

Gausality A. Musgrave 


\title{
MEMORY
}

\author{
Don Locke
}


ISBN 978-1-349-00704-2 ISBN 978-1-349-00702-8 (eBook)

DOI 10.1007/978-1-349-00702-8

(C) Don Locke 1971

Softcover reprint of the hardcover 1st edition 1971 978-0-333-10159-9

All rights reserved. No part of this publication may be reproduced or transmitted, in any

form or by any means, without permission.

First published in the United States 1971

First published in Great Britain 1971

Published by

THE MACMILLAN PRESS LTD

London and Basingstoke

Associated companies in New York Toronto

Dublin Melbourne Fohannesburg and Madras

SBN 333101596 


\section{Contents}

1: The Representative Theory 1

2: The Realist Theory 21

3: The Contemporary Approach $3^{2}$

4: The Forms of Memory 42

5: Factual Memory 51

6: Practical Memory 64

7: Personal Memory 7o

8: The Traditional Theories Reconsidered 78

9: Memory-Knowledge 92

10: Is Memory Reliable? 103

11: Our Knowledge of the Past 115

12: The Indispensability of MemoryKnowledge 132

Bibliography 138

Index 143 
MEMORY 